\title{
Microbial Condition of Water Samples from Foreign Fuel Storage Facilities
}

by

C. J. Berry

Westinghouse Savannah River Company

Savannah River Site

Aiken, South Carolina 29808

C. B. Fliermans

J. Santo Domingo

\section{MASTER}

DOE Contract No. DE-AC09-96SR18500

This paper was prepared in connection with work done under the above contract number with the U.S. Department of Energy. By acceptance of this paper, the publisher and/or recipient acknowledges the U.S. Government's right to retain a nonexclusive, royalty-free license in and to any copyright covering this paper, along with the right to reproduce and to authorize others to reproduce all or part of the copyrighted paper. 


\section{DISCLAIMER}

This report was prepared as an account of work sponsored by an agency of the United States Government. Neither the United States Government nor any agency thereof, nor any of their employees, makes any warranty, express or implied, or assumes any legal liability or responsibility for the accuracy, completeness, or usefulness of any information, apparatus, product, or process disclosed, or represents that its use would not infringe privately owned rights. Reference herein to any specific commercial product, process, or service by trade name, trademark, manufacturer, or otherwise does not necessarily constitute or imply its endorsement, recommendation, or favoring by the United States Government or any agency thereof. The views and opinions of authors expressed herein do not necessarily state or reflect those of the United States Government or any agency thereof.

This report has been reproduced directly from the best available copy.

Available to DOE and DOE contractors from the Office of Scientific and Technical Information, P.O. Box 62, Oak Ridge, TN 37831; prices available from (615) 576-8401.

Available to the public from the National Technical Information Service, U.S. Department of Commerce; 5285 Port Royal Road, Springfield, VA 22161. 


\section{DISCLAIMER}

Portions of this document may be illegible electronic image products. Images are produced from the best available original document. 


\title{
Microbial Condition of Water Samples from Foreign Fuel Storage Facilities
}

Microbial Results from 14 Foreign Water Samples Received at SRS

\author{
Prepared by
}

C. J. Berry, J. Santo Domingo, and C. B Fliermans

Environmental Biotechnology Section

October 30, 1997 


\section{SUMMARY}

In order to assess the microbial condition of foreign nuclear fuel storage facilities, fourteen different water samples were received from facilities outside the United States that have sent spent nuclear fuel to SRS for wet storage. Each water sample was analyzed for microbial content and activity as determined by total bacteria, viable aerobic bacteria, viable anaerobic bacteria, viable sulfate reducing bacteria, viable acid producing bacteria and enzyme diversity. The results for each water sample were then compared to other foreign samples and to data from the receiving basin for off-site fuel (RBOF) at SRS. Of the fourteen samples analyzed, three were considered to present a high risk to the RBOF due to the much higher microbial densities and broad enzyme diversity detected in them. In addition, seven samples had activities higher than that in the RBOF but were considered to only possess moderate risk. The remaining samples (4) had equal or less microbial activity and consequently were considered to pose little or no risk to the RBOF. These results suggest that a significant number of the foreign storage facilities have water quality standards that allow microbial proliferation and survival. Since high bacterial densities and high diversity measurements were found in these water samples, it is possible that these conditions might contribute to microbial influenced corrosion (MIC) in foreign fuel storage systems. Moreover, while the possibility of cross contamination is not known at this point, measures should be taken to monitor existing biofilms on fuels to be stored at SRS in order to reduce the potential for biocorrosion.

\section{INTRODUCTION}

Over the last decade, the deterioration of engineering materials by microorganisms has received unprecedented attention $(2,4,5,8,10,13)$, the impetus for which has been provided by significant industrial economic losses. These studies have found that steel (the material of reference) is subject to more corrosion in natural, untreated waters than in any other, more exotic environment. This is caused by the metal surface areas being brought into contact with microorganisms, which results in rapid colonization and deterioration. Any significant corrosion event occurs in the presence of, and often through, a biofilm. In practical terms, the concentration of chloride, the presence of inorganic deposits, and the concentration of oxygen are equally important; however, these parameters are frequently modified by the microbiota in a way that is deleterious to the underlying material.

The economic repercussions of corrosion, and specifically microbiologically influenced corrosion (MIC), are enormous and alarming. The losses in heavy industry are probably more evident since the post-failure investigations are more rigorous. Examples are numerous. The Canadian deuterium uranium reactors rely on the heat-exchanger alloy N08800. In the years preceding 1990, the systematic penetration of these tubes by lake water borne sulfate-reducing bacteria under a calcareous deposit led to some $\$ 13$ million in replacement costs, with $\$ 300,000 /$ day in lost energy costs (3). Estimates for unscheduled outages (down time) of U.S. nuclear utilities per 1.3 megawatt unit easily exceed $\$ 1$ million/day in 1990 dollars. Other high-cost heavy industries such as gas transmission estimate $70 \%$ of their corrosion cases to be heavily influenced by bacterial effects (1). If biofouling of engineering surfaces is also taken into account, then the cost of American petroleum refining losses alone are estimated to run at $\$ 1.4$ billion/year (12). Establishing rational estimates is difficult under the best of circumstances, however, the figures that are available in terms of biocide costs, replacement materials (upgrades), and preventative maintenance in off-line plants indicate that MIC has become a problem of truly international proportions. The industries with clearly perceptible microbiological problems include the nuclear and fossil fuel electric power generating companies (14), armaments (15), pipelines (11), pulp and paper (17), oil fields (6), and the offshore industry (9). Despite the identification of these economic impact, few original advances of a theoretical nature have been made since early in this century (18). For lack of theoretical proposals, this obscure form of corrosion has thus become phenomenological in the sense that observations have been made in the laboratory and in the field concerning the microbiological, electrochemical, and metallurgical aspects with little attempt at real integration. The clear retarding factor is the lack of technical overlap between these disciplines. 


\section{MICROBIOLOGICAL TESTING METHODS AND DESCRIPTIONS}

The Environmental Biotechnology Section (EBS) of the Savannah River Technology Center at the Savannah River Site (SRS) has examined water samples received from nine countries. These samples were pulled with sterile sample containers and shipped on ice to SRS. Upon receipt at SRS, the samples were stored at $4^{\circ} \mathrm{C}$ and analyzed for their microbiological content. The analyses consisted of three tests that determined the densities and diversities of microorganisms present in each water sample. One test measured microbial densities, as determined by the total number of organisms (viable and non-viable), while another test measured the density of specific groups of organisms (viable) associated with MIC in industrial environments. The third test measured the enzyme diversity of each sample using 96 well Biolog $®$ test plates to quantify the number of different enzymes and enzyme systems present in each sample. A detailed description of each test's protocol is listed below.

FITC Total Counts - Fifty (50) microliters ( $\mathrm{ml}$ ) of well-mixed water was spotted onto toxoplasmosis slides and heat fixed at $65^{\circ} \mathrm{C}$ for 12 minutes. The samples were then stained with fluorescein isothiocyanate (FITC) for two minutes, rinsed with deionized ultra-filtered water, and examined using epifluorescent microscopy. After counting the cells on each slide, the cellular density was calculated based on the sample volume, the area of each field for the microscope, and the total number of fields counted. Each result is presented as a total count per milliliter and represents all the microorganisms, both living and dead, that were present in the collected water sample.

Biolog® GN - Gram negative (GN) Biolog® plates consist of 96 total wells containing an indicator dye with 95 of the wells containing different organic substrates. To prepare each test plate, $150 \mathrm{ml}$ of vortexed sample water were pipetted in all the wells and allowed to incubate at $25^{\circ} \mathrm{C}$ for 28 days. Positive results were then determined visually for each plate. The results of the tests determine the diversity of the microbial community and the types of enzymes present in each water sample. The more positive wells measured for a sample the more diverse and active its microbial population, see Fliermans et. al. (7) for details.

MICKit ${ }^{\mathrm{TM}}$ III Testing - This commercially available test kits measures the density of four different populations of bacteria. These groups include aerobic, anaerobic, sulfate reducing, and acid producing bacteria. Serial dilution and aseptic techniques were used to inoculate the test kit. After 28 days of incubation the kits were visually examined for growth. The results for each test group is reported as a concentration range and enumerates the cellular concentration in counts per milliliter. The role that each group can play in general and in MIC is explained below.

Viable Aerobic Bacteria - This test estimates the total number of bacteria that live in the water sample and are able to grow in the presence of oxygen. These numbers are generally high in any circulating water systems, and are a measure of the turbidity in the system as well as its overall bacterial status.

Viable Anaerobic Bacteria - This test estimates the total number of bacteria that live in the water sample and are able to grow in the absence of oxygen. These numbers are generally low in a circulating water systems, but there may be pockets and surfaces of anaerobiosis where these bacteria can grow.

Sulfate Reducing Bacteria (SRBs) - Organism(s) that under appropriate conditions can reduce sulfate to sulfide. These bacteria are very important in causing MIC and should ideally be kept at a minimum in the spent nuclear fuel storage basin systems. If these bacteria are present in high numbers and if they are indeed active then there is a potential for the stored fuel rods to be subjected to enhanced corrosion caused by these bacteria. 
Acid Producing Bacteria (APB) - This test estimates the number of acid producing bacteria present in the sample. High densities would reflect the ability of these bacteria to produce acid and further lead to the lowering of the $\mathrm{pH}$ of the environment around a biofilm and thus facilitate biocorrosion.

The results from these tests were used to determine the risk associated with each water sample. This risk factor was determined by examining each sample for the number of different viable groups detected in each sample, the density of those groups, the diversity of each sample, and finally the viable aerobic density and total microorganism density. A rating system was developed that counted each of these parameters and then these ratings were compared with those obtained from the monthly monitoring of the RBOF and all foreign fuels. Samples with ratings lower or similar to the RBOF basin were considered to pose little or no risk to the RBOF. Samples with ratings slightly higher than the RBOF were considered to only possess moderate risk. Samples with ratings significantly higher than the RBOF were considered to present a high risk. The next section will detail and explain the results for all of the foreign samples, state a risk factor for each sample, and describe the impact of adding some of the higher risk fuels to the RBOF.

\section{RESULTS AND DISCUSSION}

The results for total direct counts and the Biolog® testing are listed in Table 1 . The bacterial density is expressed as a $\log$ value and the Biolog® results listed are listed as a percentage of positive wells from the total number of substrates. The average result of all other foreign samples analyzed at the time this report was issued and the average results from 16 months of samples taken from the RBOF at the Savannah River Site (SRS) are listed at the bottom of Table 1. The number of samples analyzed (n) for each value are listed in the right column labeled 'Sample Size'.

Nine foreign samples had higher bacterial densities than the average density measured in the RBOF basin, and five samples were more than one standard deviation greater than the average value. Twelve foreign samples had a higher percentage of positive Biolog® wells than the average from the RBOF and ten of these percentages were more than one standard deviation higher than the average $\mathrm{RBOF}$ value.

Results from the Biolog $®$ plate analyses were broken down by the different substrate groups (i.e., 11 different groups) tested. Each group consisted of different compounds of similar functional group. The number of compounds tested in each group are listed below:

\begin{tabular}{|c|c|}
\hline & polymers \\
\hline & carbohydrates \\
\hline & esters \\
\hline & carboxylic acids \\
\hline & brominated chemicals \\
\hline & amides \\
\hline & amino acids \\
\hline & aromatic compounds \\
\hline & amines \\
\hline & alcohols \\
\hline & phosphorylated chemicals \\
\hline
\end{tabular}

In Table 2, the number of positive wells for each substrate group is listed as a percentage. The average values, listed at the bottom of each part of Table 2, include the last seven months of data from the RBOF and 13 of the foreign samples. The substrate specificity was not measured for the sample from Colombia. Overall, six foreign samples had higher utilization percentages than the average RBOF sample for all substrate groups. Nine foreign samples had higher percentages than the RBOF in eight of the eleven groups while eleven samples were higher than the RBOF in six or more groups. Eight foreign samples had percentage utilization's 
greater than one standard deviation above the mean for more than five different substrate groups.

The results of the MICKit ${ }^{\mathrm{TM}}$ III test kits are shown in Table 3. Serial decimal dilutions were used to determine the density of organism in each sample so the results obtained represent a density range. For example, the result in Table 3 for the Swiss 96-HO-16 sample indicates that the density of APBs was between 1 and 10 viable cells present in each milliliter of water. More than seven foreign water samples had higher densities of SRBs than the average value measured in the RBOF. Three different foreign water samples had measurable amounts of APB, and 4 samples had measurable numbers of anaerobic bacteria. Eleven samples had higher aerobic bacterial densities than the RBOF.

Sweden FA \#2 sample received August 20, 1996

The sample received from $S$ weden had a total bacterial density slightly lower than the average value of the RBOF and the average of all foreign waters. The Biolog@ diversity measurement was higher but within one standard deviation of the average RBOF and only slightly higher than of the average foreign water samples. The water sample showed the presence of sulfate reducing bacteria and viable aerobic bacteria present in similar quantities to the RBOF water. Acid producing bacteria and anaerobic bacteria were not found. The Swedish water is somewhat similar in total microbial density to the RBOF basin. The diversity was slightly higher than that normally measured in the RBOF but well within the range of results measured. Viable sulfate reducing organisms were measured in the water but anaerobiosis was not confirmed. Overall, the water is fairly similar to that in the RBOF and is considered to have a microbial risk factor similar to the RBOF water.

Chile Reactor \#1 sample received August 21, 1996

The results from the Chilean sample suggested that a microbiological impact to the RBOF basins is expected. The data indicated that the total bacterial population present in the Chilean basin is extremely high. The density is approximately 1.5 orders of magnitude higher than the average seen in the foreign samples, and more than 2.1 orders of magnitude higher than is present in the RBOF facility. In addition, there is a large increase in the microbial diversity present as measured with the Biolog $®$ testing. The level of diversity in the Chilean basin is $96 \%$ greater than observed in the RBOF basin and $26 \%$ greater that observed for other foreign fuels coming into RBOF. Measurable densities of viable APB and anaerobic bacteria were not detected in the sample. Measurable densities of SRBs and average densities of viable aerobic bacteria comparable to the RBOF and foreign samples were observed. The higher bacterial density, diversity, viable SRB and aerobic densities suggests that a moderate risk of adverse effects is possible with the addition of the Chilean fuel.

Swiss 96-HO-16 samples received August 12, 1996

In general, the results from samples received from this location (2) were similar. The total bacterial density in each sample was higher but within one standard deviation of the average value in the RBOF, with one sample exceeded the average plus one standard deviation. The Biolog® results for both samples were significantly higher than one standard deviation above the average from the RBOF and higher but within one standard deviation of the average diversity value measured in the foreign water. All 95 wells were positive in one sample and 91 wells were positive in the other. Each water sample had densities of sulfate reducing bacteria and anaerobic bacteria greater than that found in the RBOF. APBs were measured in one sample and both samples had aerobic bacterial densities greater than the test kits could measure. The two water samples represent the highest levels of enzyme diversity and anaerobic bacteria measured in foreign waters. The presence of sulfate reducing and anaerobic bacteria indicate that conditions existed in the water that were very conducive to microbial corrosion. The risk of this water compared to that of the RBOF is very high.

Germany FMBR samples received August 8, 1996

The total bacterial densities of the two samples received from this location (\#1 and \#2) were more than an order of magnitude higher than the average RBOF density and higher than the average foreign water density. Diversity measurements were quite different in each sample. 
Sample \#2 had all but two of the wells read positive while the other sample had nearly $50 \%$ fewer positive wells. Very high densities of SRBs and viable aerobic bacteria were measured in both samples. There were no viable anaerobic bacteria detected in either sample but sample \#1 had detectable amounts of APBs. Overall, samples \#1 and \#2 represents a higher risk than the RBOF water because of the high density of viable aerobic bacteria, viable SRBs, and total bacterial densities. In addition, the high diversity measured in sample \#2 adds to the risk factor determined for this water sample and is considered a very high risk to the RBOF.

Germany GKSS sample received August 16, 1996 The sample received from Germany had a total bacterial density higher than one standard deviation above the average value of the RBOF and the average of all foreign waters. The Biolog® diversity measurement was similar to the average from the RBOF and lower but within one standard deviation of the average of foreign water samples. The water sample showed the presence of sulfate reducing bacteria but did not show any viable APB, anaerobic and no viable aerobic bacteria were detected in the sample. Although SRBs and total bacterial densities are relatively high, the risk factor of the water is moderate in comparison with the RBOF water due to the relatively low enzyme diversity and no detectable APBs and anaerobic bacteria in these samples.

Colombia sample received September 13, 1996

The sample received from Colombia had a total bacterial density higher but within one standard deviation of the average value of the RBOF and the average of all foreign waters. The Biolog® diversity measurement was significantly higher than one standard deviation of the average from the RBOF and higher but within one standard deviation of the average of foreign water samples. The water sample showed the presence of high densities of sulfate reducing bacteria and viable aerobic bacteria. A small number of anaerobic bacteria were measured, but no APB were detected. This water has a slightly higher total bacterial density, viable aerobic density, viable anaerobic density, significantly higher diversity and SRB density. The low numbers of sulfate reducing and anaerobic bacteria and the relatively high diversity suggest that this water has a moderate risk factor in comparison to the RBOF water.

Canada sample received January 14,1997

The results from the single water sample collected from Canada indicated that no microbiological impacts to the RBOF are expected. The total bacterial densities in the Canadian basin is 2 orders of magnitude less than the average seen in the other foreign fuel basins, and 1.5 orders of magnitude less than is currently present in the RBOF facility. In addition, a relatively low microbiological diversity was observed as suggested by the Biolog(ß) test results. The level of diversity in the Canadian basin is $57 \%$ less than observed in the RBOF basin and $73 \%$ below that observed for other foreign fuels coming into RBOF. The reduced bacterial concentration and the reduction in the Biolog@ diversity of the Canadian basin suggest that no adverse microbiological effect is expected from the Canadian fuels.

Germany Pool \#167 sample received January 14, 1997 The results from the single water sample collected from the German Pool \#167 suggested that no microbiological impacts to the RBOF basins are expected. The total bacterial densities in the German basin was 1.5 orders of magnitude less than the average seen in the other foreign fuel basins, and 1 orders of magnitude less than is currently present in the RBOF facility. A reduced microbiological diversity was observed in the Biolog® plates. The level of diversity in the German basin is $27 \%$ less than observed in the RBOF basin and $53 \%$ below the diversity observed for other foreign fuels coming into RBOF. The reduced bacterial concentration and the relatively low Biolog $\left(B^{\circ}\right.$ diversity of the German basin clearly indicate that no adverse microbiological effect is expected from the German fuels.

England sample received April 1, 1997

The results from the single water sample collected from the English pool suggested that the risk of microbiological impact to the RBOF basins is probable. The total bacterial densities in the English basin is approximately equal to the average seen in the foreign samples, and slightly higher than is present in the RBOF facility. However, there is a large increase in the 
microbial diversity present as measured with the Biologß testing. The level of diversity in the English basin is $113 \%$ greater than observed in the RBOF basin and $37 \%$ greater that observed for other foreign fuels coming into RBOF. Measurable densities of viable SRB and anaerobic bacteria were not detected in the sample. Measurable densities of APB and very high densities of viable aerobic bacteria were measured. The viable aerobic bacterial densities were more than 2 orders of magnitude greater than the average value from the RBOF and almost 2 orders of magnitude higher than the average of all foreign samples. The increased diversity, viable APB and aerobic densities suggest that a moderate risk of adverse effects is possible with the addition of the English fuel.

Japan sample received April 8, 1997

The results from the single water sample collected from the Japanese pool suggested that only a slight microbiological impact to the RBOF basins is expected. The total bacterial densities in the Japanese basin is 1.2 orders of magnitude less than the average seen in the other foreign fuel basins, and 0.6 orders of magnitude less than is currently present in the RBOF facility. However, there is an increase in the microbial diversity present as measured with the Biologß testing. The level of diversity in the Japanese basin is $102 \%$ greater than observed in the RBOF basin and $30 \%$ greater that observed for other foreign fuels coming into RBOF. The viable aerobic density was more than 2 orders of magnitude greater than the average value from the RBOF and almost 2 orders of magnitude higher than the average of all foreign samples. No viable SRB, APB and anaerobic bacteria were detected in the sample. The low bacterial concentrations indicate that no additional risk would add to the SRS system, however, the increase in diversity show that a slight risk would be added to the SRS basins by this fuel.

Italy sample received March 31, 1997

The results from the single water sample collected from the Italian pool suggested that risk of microbiological impact to the RBOF basins is possible. The total bacterial densities in the Italian basin is approximately equal to the average seen in the other foreign fuel basins, and slightly higher than is currently present in the RBOF facility. However, there is an increase in the microbial diversity present as measured with the Biolog ${ }^{\circledR}$ testing. The level of diversity in the Italian basin is $89 \%$ greater than observed in the RBOF basin and $21 \%$ greater that observed for other foreign fuels coming into RBOF. Measurable densities of viable SRB and anaerobic bacteria were detected in the sample. The viable aerobic density was more than 2 orders of magnitude greater than the average value from the RBOF and almost 2 orders of magnitude higher than the average of all foreign samples. The high diversity, viable anaerobic coupled with viable SRBs density indicate that a moderate risk of adverse effects is possible with the addition of the Italian fuel.

Germany FMR/GKAA sample received July 15, 1997

The results from the single water sample collected from the German pool suggested that only slight microbiological impacts to the RBOF basins are expected. The total bacterial densities in the German basin is 1.5 orders of magnitude less than the average seen in the other foreign fuel basins, and 1 orders of magnitude less than is currently present in the RBOF facility. However, this sample had a relatively high microbial diversity as determined by the Biologß tests. The level of diversity in the German basin is $78 \%$ greater than observed in the RBOF basin and $14 \%$ greater than the observed for other foreign fuels coming into RBOF. No viable SRBs, APBs and anaerobic bacteria were detected in the sample. The reduced bacterial concentrations suggest that no additional risk would add to the SRS system, however, the increases in diversity show that a slight risk would be added to the RBOF by this fuel.

RBOF Parameters After Foreign Fuel Addition

Since introduction of the fuel with high risk factors into the RBOF the microbial analyses have shown an increase in some microbial parameters and decrease in others. Figure 1 shows the average values before and after addition of this fuel with standard deviation error bars. Eight months of sample results prior to addition and eight months of results after addition of this fuel were examined for and changes in any of the microbial parameters. Overall, the mean diversity, APBs density, anaerobe density, and aerobe density parameters have increased since addition of the fuel while the mean total bacterial and viable SRB densities have decreased. 
Statistical analysis of the results before and after introduction of the high risk fuel using a $t$-test determined that the increase in diversity and decrease in SRB density were significant $(\mathrm{P}<$ $0.00001)$. Changes in the other parameters were not found to be significant.

Operational changes to the facility, physical movement of the fuel within the facility, and changes in the water quality will also effect these microbial parameters. The reduction of SRBs indicate that the conditions for sulfate reduction were mitigated either through changes in the water quality or surface environments. Operational changes to the RBOF may have impacted this bacterial group. Prior to the fuel addition, the RBOF operations began treating the interphase of the water and the pool wall with $30 \%$ hydrogen peroxide. In addition, the overhead lights are now shut off during off-shift hours. These two changes have decreased the amount of carbon entering the basin system and removed a very active biofilm with the peroxide treatment. The increase in diversity can not be attributed to the use of peroxide or the reduced lighting and could be due to the addition of foreign fuel or even an increase in the physical movement of the fuels within the basins. The overall effect, if any, of foreign fuel addition on the microbial quality of the RBOF water is still not clear.

Surface analysis of the fuel or material similar in structure to the fuel casks is required. Surface monitoring the fuel cask surface has not been done. However, a coupon monitoring program designed specifically for microbial surveillance has been established. Unfortunately, the coupons were placed in the basins after addition of the high risk fuel. In the future, these coupons will allow us to determine the temporal and spatial status of the microbial biofilms, changes in the corrosion rates to these coupons, and provide us with a fuel sentinel analogue for the fuel cask. Continued monitoring of the fuel water as well as the fuel coupons is essential to maintaining good control of any MIC processes occurring now or in the future.

\section{CONCLUSIONS AND PATH FORWARD}

Fourteen water samples from nine different counties were analyzed for microbial content and activity as determined by bacterial density and diversity tests. These results were then compared to other foreign samples and samples from the RBOF, here at SRS. Of the fourteen samples analyzed, three were considered to present a high risk to the RBOF due to their high densities of viable organisms associated with MIC and their very broad enzyme diversity. Seven samples had overall microbial activities higher than that historically measured in the RBOF and four samples had equal or less microbial activity than the RBOF and consequently were considered to pose little or no risk. These results suggest that a significant number of the foreign storage facilities have water quality standards that allow microbial proliferation and survival. Due to the long term storage of fuels in these waters it is possible that the foreign fuels may have microbial films that have the potential to impact the SRS basins.

Thus far, results from water samples analyzed for microbial content and activity suggests the presence of high bacterial numbers and diversity within foreign storage facilities fuels received at SRS. Although our investigations have not established a link between the addition of foreign fuel and changes in microbial parameters at the RBOF because of basin operation changes that occurred prior and during addition of the foreign fuel, different levels of risk were identified. Since the possibility of cross contamination is not known at this point, measures should be taken to monitor existing biofilms on fuels to be stored at SRS in order to reduce the potential for biocorrosion. Therefore, we recommend that the monitoring of foreign water samples should be continued especially since the enzymatic and microbial diversity of the sampled $\mathrm{RBOF}$ water has increased. It is also recommended to continue the coupon surveillance program and to include a better characterization of the microorganisms within the SRS storage facilities. These studies will not only facilitate our overall understanding of MIC, but allow us to take rapid corrective or prophylactic action should it become necessary. 


\section{REFERENCES}

1. Allred, R, 1. Sudbury, and D. C. Olson. 1959. Corrosion is controlled by bactericide treatment. World Oil 149: 111-112.

2. Angell, P., S. Borenstein, R. Buchanan, S. Dexter, N. Dowling, B. Little, C. Lundin, M. McNeil, D. Pope, R. Tatnall, D. White, and G. Ziegenfuss (ed.). 1995. International Conference on Microbially Influenced Corrosion. National Association of Corrosion Engineers, Houston.

3. Brennenstahl, A. M., and P. E. Doherty. 1990. The economic impact of microbiologic!ly influenced corrosion at Ontario hydro's nuclear power plants, p. 7/57/10. In N. 1. E. Dowling, M. W. Mittelman, and J. C. Danko (ed.), Proceedings of Conference: Microbially Influenced Corrosion and Deterioration Center for Materials Processing, University of Tennessee, Knoxville.

4. Dexter, S. (ed.). 1986. Biologically Induced Corrosion NACE-8 Proceedings of the Internanonal Conference on Biologically Induced Corrosion. National Association of Corrosion Engineers, Houston.

5. Dowling, N. 1. E., M. W. Mittelman, and 1. C. Danko (ed.). 1990. Proceedings of Congress, Microbially Influenced Corrosion and Deterioration. University of Tennessee Knoxville.

6. Farquhar, G.1974. The sulfate-reducing bacteria and oilfield bacterial corrosion. A review of the current state of the art, article 1. In Proceedings of Conference, Corrosion '74. National Association of Corrosion Engineers, Houston.

7. Fliermans, C. B., Franck, M. M., Hazen, T. C., and Gorden, R. W. 1997. Ecofunctional enzymes of microbial communities in ground water. Federation of European Microbiological Societies Microbiological Reviews, 20: 379-389.

8. Franklin, M. 1., D. C. White, and H. S. Isaacs. 1991. Spatial and temporal relationships between localized microbial metabolic activity and localized electrochemical activity on steel, In Proceedings of Conference, Corrosion '91. National Association of Corrosion Engineers, Houston.

9. Hill, E. C. 1987. Microbial Problems in the Off-Shore Oil Industry. Institute of Petroleum, London.

10. Hóweam, P. (ed.). 1990. Microbiology in Civil Engineering. FEMS symposium 59. Chapman \& Hall, London. Corrosion rates of carbon steel by combinations of Bacillus sp., Hatnia alvei and Desuliovibrio gigas established by phospholipid analysis of electrode biofilm. Corros. Sci. 33(12): 1843-1853.

11. Kasahara, K., and F. Kajiyama. 1986. Role of sulfate-reducing bacteria in the localized corrosion of buried pipes, p. 172-183. In S. Dexter (ed.), Biologically Induced Corrosion. NACE-8. Proceedings of the International Conference on Biologically Induced Corrosion. National Association of Corrosion Engineers. Houston.

12. Knudsen, J. G. 1981. Fouling of heat transfer surfaces, p. 57-82. In Power Condenser Heat Transfer Technology. Hemisphere Publishing Co., New York.

13. Lawrence, J. R., G. M. Wolfaardt, and D. R. Korber. Determination of diffusion coefficients in biofilms by confocal laser microscopy. Appl. Environ. Microbiol. 60: 11661173.

14. Licina, G. 1989. Microbial Corrosion: 1988 Workshop Proceedings. ER-6345. Electric Power Research Institute, Palo Alto, Calif. 
15. Little, B., M. Walch, P. Wagner, S. Gerchalkov, and R. Mitchell. 1984. The impact of extreme obligate bacteria on corrosion processes, p. 511-520. In Proceedings of 6th International Congress on Marine Corrosion and Fouling.

16. Rodriguez-Leiva, M., and H. Tributsch. 1988. Morphology of bacterial leaching patterns by Thiobacillus ferroxidans on synthetic pyrite. Arch. Microbiol. 149:401-405

17. Soimajarvi, 1., M. Pursiainen, and 1. Korhonen. 1978. Sulphate-reducing bacteria in paper machine waters and in suction roll perforations. Eur. J. Appl. Microbiol. Biotechnol. 5:87-93.

18. Von Volzagen Kuhr, C. A. H., and 1. S. van der Vlught. 1934. Graphatization of cast iron as an electrochemical process in anaerobic soils. Water 18:147-165. 


\section{TABLES AND FIGURES}

Table 1. Total Direct Counts and Biolog® Results

\begin{tabular}{|c|c|c|c|}
\hline Sample ID & $\begin{array}{c}\text { Bacterial Density } \\
\log (\text { count } / \mathrm{ml})\end{array}$ & $\begin{array}{c}\text { Biolog@ Result } \\
\text { \# Positive }(\%)\end{array}$ & $\begin{array}{c}\text { Sample Size } \\
\text { (n) }\end{array}$ \\
\hline Sweden & 5.65 & 72 & 1 \\
\hline Chile & 7.83 & 88 & 1 \\
\hline Swiss $96-\mathrm{HO}-16$ & 7.32 & 96 & 1 \\
\hline Swiss 96-HO-16 & 6.50 & 99 & 1 \\
\hline Germany FMBR \#1 & 7.67 & 47 & 1 \\
\hline Germany FMBR \#2 & 7.05 & 97 & 1 \\
\hline Germany GKSS & 7.75 & 47 & 1 \\
\hline Colombia & 6.63 & 88 & 1 \\
\hline Canada & 4.32 & 19 & 1 \\
\hline Germany \#167 & 4.85 & 33 & 1 \\
\hline Japan & 5.18 & 91 & 1 \\
\hline England & 6.34 & 96 & 1 \\
\hline Italy & 6.31 & 85 & 1 \\
\hline Germany & 4.77 & 80 & 1 \\
\hline SRS RBOF Basin & $5.72 \pm 1.16$ & $45 \pm 22$ & 152 \\
\hline Foreign Samples & $6.30 \pm 1.18$ & $70 \pm 26$ & 14 \\
\hline
\end{tabular}

\pm values equal to one standard deviation based on the sample size (n). 
Table 2. Biolog® Organic Utilization Results

\begin{tabular}{|c|c|c|c|c|c|c|}
\hline Sample ID & $\begin{array}{c}\text { Sample Size } \\
\text { (n) }\end{array}$ & $\begin{array}{c}\text { Polymers } \\
\% \text { Positive }\end{array}$ & $\begin{array}{c}\text { Carbohydrates \% } \\
\text { Positive }\end{array}$ & $\begin{array}{c}\text { Esters \% } \\
\text { Positive }\end{array}$ & $\begin{array}{c}\text { Carboxylic Acid } \\
\% \text { Positive }\end{array}$ & $\begin{array}{c}\text { Brominated } \\
\text { Chemicals \% } \\
\text { Positive }\end{array}$ \\
\hline Sweden FA \#2 & 1 & 100 & 83 & 50 & 50 & 100 \\
\hline Chile Reactor 1 & 1 & 80 & 93 & 100 & 75 & 100 \\
\hline Swiss 96-HO-16 & 1 & 100 & 100 & 100 & 100 & 100 \\
\hline Swiss 96-HO-18 & 1 & 100 & 100 & 100 & 92 & 100 \\
\hline $\begin{array}{c}\text { Germany FMBR } \\
\text { \#1 }\end{array}$ & 1 & 100 & 100 & 100 & 96 & 100 \\
\hline $\begin{array}{c}\text { Germany FMBR } \\
\text { \#2 }\end{array}$ & 1 & 20 & 41 & 50 & 50 & 100 \\
\hline Germany GKSS & 1 & 40 & 41 & 100 & 29 & 0 \\
\hline Colombia & 0 & $\mathrm{ND}$ & $\mathrm{ND}$ & $\mathrm{ND}$ & $\mathrm{ND}$ & $\mathrm{ND}$ \\
\hline Canada & $\mathbf{1}$ & 0 & 21 & 0 & 33 & 0 \\
\hline Germany \#197 & 1 & 20 & 38 & 50 & 50 & 100 \\
\hline Japan & $\mathbf{1}$ & 100 & 97 & 100 & 96 & 100 \\
\hline England & 1 & 100 & 97 & 100 & 100 & 100 \\
\hline Italy & 1 & 80 & 76 & 100 & 92 & 100 \\
\hline Germany & 1 & 80 & 86 & 100 & 100 & 100 \\
\hline $\begin{array}{c}\text { SRS RBOF } \\
\text { Basin }\end{array}$ & $\mathbf{4 8}$ & $\mathbf{6 6} \pm \mathbf{2 7}$ & $\mathbf{5 3} \pm \mathbf{2 2}$ & $\mathbf{6 9} \pm \mathbf{3 4}$ & $\mathbf{6 2} \pm \mathbf{2 0}$ & $\mathbf{6 7} \pm \mathbf{4 8}$ \\
\hline $\begin{array}{c}\text { Foreign } \\
\text { Samples }\end{array}$ & $\mathbf{1 2}$ & $\mathbf{7 1} \pm \mathbf{3 7}$ & $\mathbf{7 5} \pm \mathbf{3 9}$ & $\mathbf{8 1} \pm \mathbf{3 3}$ & $\mathbf{7 4} \pm \mathbf{2 7}$ & $\mathbf{8 5} \pm \mathbf{3 8}$ \\
\hline
\end{tabular}

\begin{tabular}{|c|c|c|c|c|c|c|}
\hline Sample ID & $\begin{array}{c}\text { Amides \% } \\
\text { Positive }\end{array}$ & $\begin{array}{c}\text { Amino Acids } \\
\% \text { Positive }\end{array}$ & $\begin{array}{c}\text { Aromatic } \\
\text { Chemicals } \\
\text { \% Positive }\end{array}$ & $\begin{array}{c}\text { Amines \% } \\
\text { Positive }\end{array}$ & $\begin{array}{c}\text { Alcohol \% } \\
\text { Positive }\end{array}$ & $\begin{array}{c}\text { Phosphorylated } \\
\text { Chemicals \% } \\
\text { Positive }\end{array}$ \\
\hline Sweden FA \#2 & 100 & 85 & 100 & 67 & 50 & 100 \\
\hline Chile Reactor 1 & 100 & 95 & 100 & 100 & 50 & 100 \\
\hline Swiss 96-HO-16 & 100 & 100 & 100 & 100 & 50 & 100 \\
\hline Swiss 96-HO-18 & 100 & 95 & 100 & 100 & 50 & 67 \\
\hline $\begin{array}{c}\text { Germany FMBR } \\
\# 2\end{array}$ & 100 & 96 & 100 & 100 & 100 & 100 \\
\hline $\begin{array}{c}\text { Germany FMBR } \\
\# 1\end{array}$ & 33 & 60 & 50 & 67 & 50 & 67 \\
\hline Germany GKSS & 0 & 70 & 100 & 67 & 50 & 33 \\
\hline Colombia & ND & ND & ND & ND & ND & ND \\
\hline Canada & 0 & 20 & 0 & 0 & 0 & 0 \\
\hline Germany \#197 & 33 & 25 & 0 & 0 & 50 & 0 \\
\hline Japan & 67 & 95 & 75 & 100 & 50 & 0 \\
\hline England & 100 & 100 & 75 & 100 & 50 & 67 \\
\hline Italy & 100 & 100 & 100 & 100 & 50 & 33 \\
\hline Germany & 67 & 85 & 0 & 0 & 50 & 67 \\
\hline $\begin{array}{c}\text { SRS RBOF } \\
\text { Basin }\end{array}$ & $\mathbf{7 2} \pm \mathbf{2 9}$ & $\mathbf{5 7} \pm \mathbf{2 5}$ & $\mathbf{3 2} \pm \mathbf{2 5}$ & $\mathbf{3 1} \pm \mathbf{3 8}$ & $\mathbf{4 4} \pm \mathbf{2 7}$ & $\mathbf{2 4} \pm \mathbf{3 8}$ \\
\hline $\begin{array}{c}\text { Foreign } \\
\text { Samples }\end{array}$ & $\mathbf{6 9} \pm \mathbf{4 0}$ & $\mathbf{7 9} \pm \mathbf{2 8}$ & $\mathbf{6 9} \pm \mathbf{4 2}$ & $\mathbf{6 9} \pm \mathbf{4 2}$ & $\mathbf{5 0} \pm \mathbf{2 0}$ & $\mathbf{5 6} \pm \mathbf{3 9}$ \\
\hline
\end{tabular}


Table 3. MICKit ${ }^{\text {TM }}$ III Results

\begin{tabular}{|c|c|c|c|c|c|}
\hline Sample ID & $\begin{array}{c}\text { SRB } \\
\text { Density Log } \\
\text { (\#/ m1) }\end{array}$ & $\begin{array}{l}\text { APB Density } \\
\log (\# / \mathrm{ml})\end{array}$ & $\begin{array}{c}\text { Anaerobe Density } \\
\log (\# / \mathrm{ml})\end{array}$ & $\begin{array}{l}\text { Aerobe Density } \\
\text { Log }(\# / \mathrm{ml})\end{array}$ & $\begin{array}{l}\text { Sample Size } \\
\text { (n) }\end{array}$ \\
\hline Sweden FA \#2 & $2-3$ & 0 & 0 & $>5$ & 1 \\
\hline Chile Reactor 1 & $>5$ & 0 & 0 & $3-4$ & 1 \\
\hline Swiss 96-HO-16 & $>5$ & $0-1$ & $2-3$ & $>5$ & 1 \\
\hline Swiss 96-HO-18 & $3-4$ & 0 & $0-1$ & $>5$ & 1 \\
\hline Germany FMBR \#1 & $>5$ & $0-1$ & 0 & $>5$ & 1 \\
\hline Germany FMBR \#2 & $>5$ & 0 & 0 & $>5$ & 1 \\
\hline Germany GKSS & $>4$ & 0 & 0 & 0 & 1 \\
\hline Colombia & $>5$ & 0 & $0-1$ & $>5$ & 1 \\
\hline Canada & 0 & 0 & 0 & $1-2$ & 1 \\
\hline Germany Pool \#197 & 0 & 0 & 0 & $>5$ & 1 \\
\hline Japan & 0 & 0 & 0 & $>6.39$ & 1 \\
\hline England & 0 & $0-1$ & 0 & $>6.39$ & 1 \\
\hline Italy & $0-1$ & 0 & $0-1$ & $>6.39$ & 1 \\
\hline Germany & 0 & 0 & 0 & $5.11-6.39$ & 1 \\
\hline SRS RBOF Basin & $\begin{array}{r}2.28 \\
\pm 2.13 \\
\end{array}$ & $0.49 \pm 0.90$ & $0.37 \pm 0.81$ & $4.26 \pm 1.05$ & 140 \\
\hline Foreign Samples & $\begin{array}{c}2.93 \pm \\
2.17\end{array}$ & $\begin{array}{c}0.23 \\
0.43\end{array}$ & $0.46 \pm 0.88$ & $4.53 \pm 1.73$ & 14 \\
\hline
\end{tabular}

\pm values equal to one standard deviation based on the entire sample size (n) for SRS RBOF and Foreign sample results the range for the sample from each foreign sample. 
Figure 1. Microbial Parameters From the RBOF Before and After Addition of High Risk Fuel

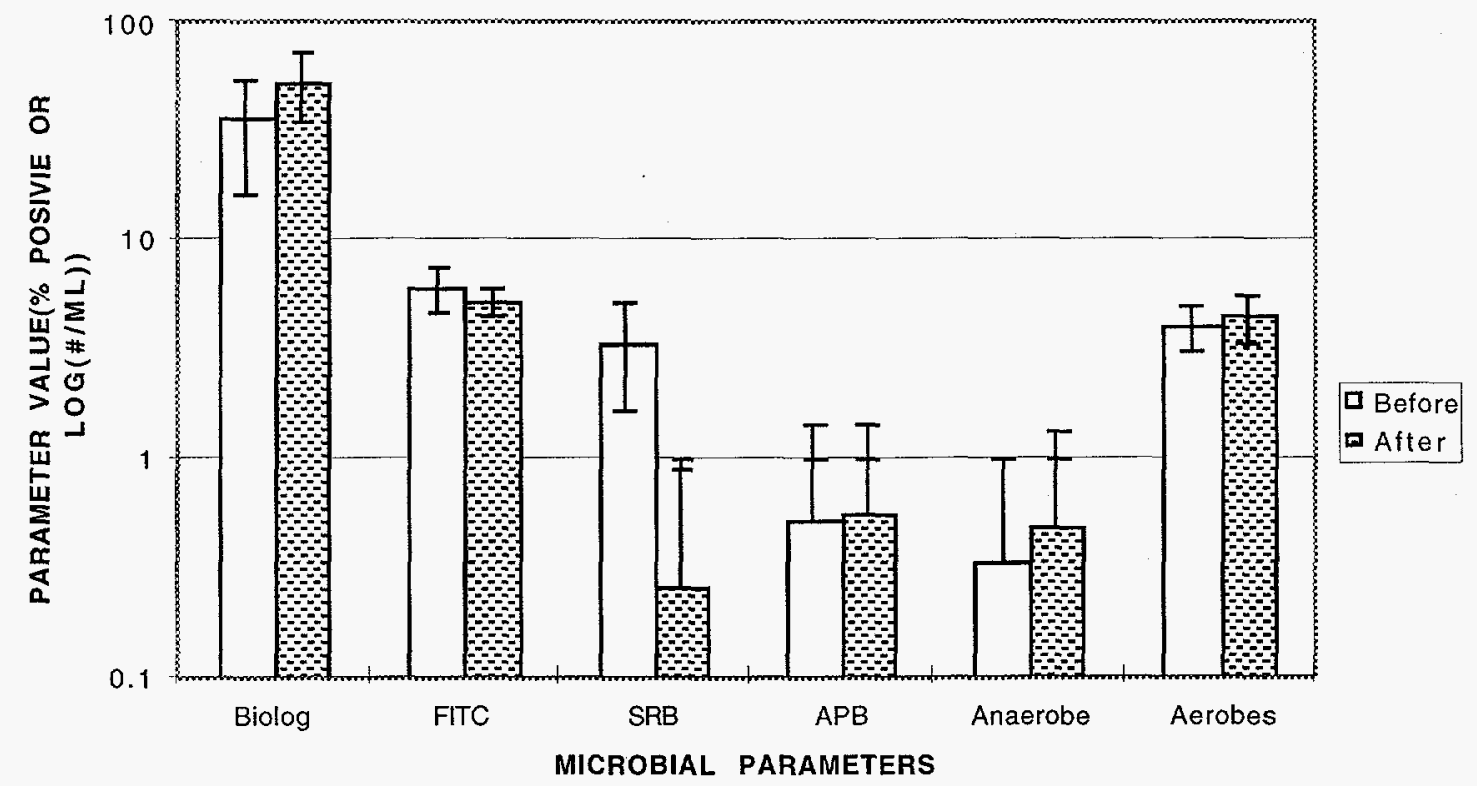

